\title{
Front Matter: Volume 11771
}

, "Front Matter: Volume 11771," Proc. SPIE 11771, Quantum Optics and Photon Counting 2021, 1177101 (12 May 2021); doi: 10.1117/12.2598956 SPIE. Event: SPIE Optics + Optoelectronics, 2021, Online Only 


\title{
Quantum Optics and Photon Counting 2021
}

\author{
Ivan Prochazka \\ Martin Štefaňák \\ Roman Sobolewski \\ Aurél Gábris \\ Editors
}

19-23 April 2021

Online Only, Czech Republic

Sponsored by

SPIE

Cooperating Organisations

EU Bea mlines (Czech Republic)

Laserlab Europe

European Optic al Soc iety

HiLASE Centre (Czech Republic)

Published by

SPIE 
The papers in this volume were part of the technical conference cited on the cover and title page. Papers were selected and subject to review by the editors and conference program committee. Some conference presentations may not be available for publication. Additional papers and presentation recordings may be a vaila ble online in the SPIE Digital Libra ry at SPIEDigita lLibrary.org.

The papers reflect the work and thoughts of the authors and a re published herein as submitted. The publisher is not responsible for the valid ity of the information or for any outc omes resulting from reliance thereon.

Please use the following format to cite material from these proceedings:

Author(s), "Title of Paper," in Quantum Optic sand Photon Counting 2021, edited by Ivan Prochazka, Martin Štefaňák, Roman Sobolewski, Aurél Gábris, Proc. of SPIE 11771, Seven-digit Article CID Number (DD/MM/YYYY); (DOI URL).

ISSN: 0277-786X

ISSN: 1996-756X (electronic)

ISBN: 9781510643765

ISBN: 9781510643772 (electronic)

Published by

SPIE

P.O. Box 10, Bellingham, Wa shington 98227-0010 USA

Telephone +1 3606763290 (Pacific Time)

SPIE.org

Copyright @ 2021 Society of Photo-Optic al Instrumentation Engineers (SPIE).

Copying of material in this book for intemal or personal use, or for the intemal or personal use of specific clients, beyond the fair use provisions granted by the U.S. Copyright Law is authorized by SPIE subject to payment of fees. To obta in permission to use and sha re a ricles in this volume, visit Copyright Clearance Center at copyright.com. Other copying for republication, resale, advertising or promotion, or any form of systematic or multiple reproduction of any material in this book is prohibited except with pemission in writing from the publisher.

Printed in the United States of America by Curran Associates, Inc., under license from SPIE.

Publication of record for individual papers is online in the SPIE Digital Library.

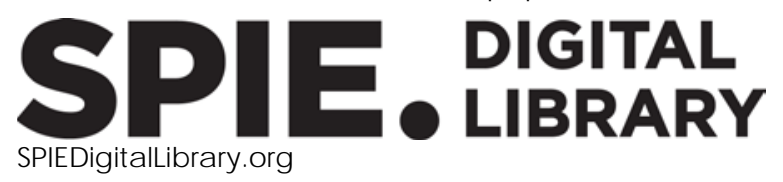

\footnotetext{
Paper Numbering: A unique c itation identifier (CID) number is a ssigned to each artic le in the Proceedings of SPIE at the time of public ation. Utilization of CIDs a llows a rtic les to be fully citable as soon as they a re published online, and connects the same identifier to all online and print versions of the public ation. SPIE uses a seven-digit CID article numbering system structured as follows: - The first five digits correspond to the SPIE volume number.

- The last two digits indic ate public ation order within the volume using a Base 36 numbering system employing both numerals and letters. These two-number sets start with $00,01,02,03,04$, $05,06,07,08,09,0 A$, OB ... 0Z, followed by 10-1Z, 20-2Z, etc. The CID Number appears on each page of the manuscript.
} 


\section{Contents}

SUPERCONDUC TING NANOSTRIPE SINGLE PHOTON DETECTORS(SNSPDS)

$1177107 \quad$ High-efficiency mult-element superconducting single-photon detector[11771-4]

SINGLE PHOTON AVALANCHE DIODES (SPADS)

11771 OA Linear SPAD anay for quantum communication (Invited Paper) [11771-7]

11771 OB Design of a 24×24 SPAD imager for multi-photon coincidence-detection in super resolution mic roscopy [11771-8]

11771 OC Towards low-timing jitter photon number-resolved digital silic on photomultipliers [11771-9]

11771 OD Time-gated 128x1 and 8x8 SPAD cameras for 2D photon-counting and 3D time-of-fight maps [11771-10]

11771 OE Double feature, digital and analog, 5×5 SPADs single-photon camera [11771-11]

11771 OF SPAD amay for LDAR with region-of-interest selection and smart TDC routing [11771-12]

11771 OG Use a novel figure of menit to evaluate the overall performance of SPAD [11771-27]

PHOTON COUNTING APPUCATIONS

$11771 \mathrm{OH} \quad$ Space qualified quadruple photon counting detec tor based on silic on SPAD (Invited Paper) [11771-13]

117710 J The significance of the spectral correction of photon counting detector response in material classific ation from spectral x-ray CT[11771-15]

11771 OK Visualization of light transmission in the brain using photon tracking based on the Monte Carlo method [11771-16]

11771 OL DNA and nanotechnology [11771-17] 
11771 ON Preliminary progress of the state preparation with a new optical pumping method in a cesium atomic fountain clock [11771-19]

$11771 \mathrm{OP} \quad$ Coherent resonance energy tansfer dynamics of super-Ohmic environments experienc ing loganithmic perturbations using full-polaron transformation-based approach and its performance [11771-21]

11771 OQ Multi-site exciton energy transfer dynamics in super Ohmic environments experiencing logarithmic perturbations using full polaron tansformation-based quantum master equation [11771-22]

\section{QUANTUM DOTS AND AMPUFERS}

11771 OR Influence of Sb composition on the band alignment and optical characteristics of strain coupled vertically aligned InAs/ GaAsSb quantum dots [11771-23]

11771 0S Effect of GaAs1-xN $\mathbf{N}_{\mathbf{x}}$ capping layer on the strain profile and emission PL wavelength of InAs quantum dot heterostructures using digital alloy approach [11771-24]

11771 0T Optical and structural investigation of multilayer InAs SK QDs with In0.15Ga0.85As strain-reducing layer electronically coupled to SMLQDs grown by molecular beam epitaxy [11771-25] 